海洋出版編 : 地質学と地震一松田時彦教授退官 記念号一月刊地球, 号外 No. 5, 海洋出版, 1992 年 4 月, B5 判, 217 ページ, 6, 000 円.

本書は松田時彦先生の東京大学地震学研究所退官 を記念してつくられた, 『月刊地球』の号外特集号 である. 松田時彦先生といえば，地形学を少しでも かじったことのある人にとっては, 一種の憧れのよ うなものを感じさせられる存在であろう. 先生は地 形学者ではなく地質学者だが, ネオテクトニクスや プレートテクトニクス研究の旗頭の一人として，日 本の地形学の発展にきわめて大きい役割を果たされ た. 地理学や第四紀学にも非常にかかわりの深い学 者である。

さて地質学者の退官記念号などというと, 内容が いかにも硬そうな予感がして，もうそれだけで敬遠 する人が出てきそうである. しかしこの特集号を読 み始めれば，そんな先入観はたちまちふっとんでし まうに違いない，一般書を含め, 評者にとってこれ ほどおもしろい書物は本当に久し振りであった。

この本は大学教授の退官を記念した書物としては, いろいろな面で異色である，編集も内容もいわゆる 退官記念論文集の体裁はとっていない，普通にいう 記念論文もあるが，それ以外にご本人の研究の回顧 と弟子たちによる業績の紹介があり，さらにプレー トテクトニクスの研究史と, 先生や研究をめぐる思 い出，随想までが一冊にまとめられている．したが って執筆者は優に 50 人を越え，内容も実に多岐に わたることになった.

内容を簡単に紹介しよう。読みでがあるのはやは り先生本人の回顧と, 山崎晴雄らによる業績の紹介 である. 松田先生の研究は南部フォッサマグナの地 質之いうきわめてオーソドックスな地質の調査から 始まり, 水底火山性堆積物の研究を経て, しだいに プレートテクトニクスの研究と, ライフワークとな る活断層を中心とするネオテクトニクスへと移行し ていく.これは同一人物の研究亡は思えないような, 大きなテーマの移り変わりである. 何がこうしたテ 一マの変更のきっかけとなり，そのとき何を考えた か. 本書では, 論文ではうかがい知ることのできな い思考の過程が, 当時の研究をめぐる状況や雾囲気
とともにいきいきと記述されている，何年か前，評 者は千葉徳爾先生の本の書評で, 優れた研究者はき ちんとした自分の研究史を書くべきだと書いたこと があるが，本書に収録された先生の回顧は，まさに この注文よ゙おりの優れた自分史になっているといえ そうである. 今後, ネオテクトニクスなどの研究を 志す学生諸君などによっては，この回顧の文と業績 の紹介は，研究を進めるうえの必読文献となるだろ う. また先生のきわめて精力的な研究の歩みは, 巻 末の 200 編を越す優れた論文や報告書のリストと ともに，怠け者の地理学者をおおいに刺激してくれ るに違いない（平均すると 30 数年間なんと 2 力月 に 1 編ずつ論文か報告書を書いていたことになる). 本文の紹介に移ろう。全体が 5 部に分けられてい るが，第 1 部「プレートテクトニクスが成立した 頃」が抜群におもしろい. プレートテクトニクスを めぐっては, 周知のように東大地質学教室を中心之 するプレートテクトニクス容認派と, 井尻正二や藤 田至則ら地学団体研究会に依拠する反プレート派上 の間に, 激しい論争があった。これは科学史的にみ ても非常に興味深い事件になっているが，本誌では じつに珍しいことに, 両派によってその論争の経過 が回顧されている，たとえばプレート派は

「プレート・テクトニクスの成立した頃のことと， 日本におけるプレート反対運動」(都城秋穂)

「プレートテクトニクスと日本の地質学界—— の 10 年の空白一」(藤田和夫)

「プレートテクトニクスについての個人的経験」 （堀越 铱）

などで反プレート派に対する恨みを述べ，反プレー ト派は

「プレートテクトニクスの批判について」（藤田至 則)

「地学団体研究会は日本のプレートテクトニクス に関する研究を 10 年遅らせたか」（端山好和） でこれに反論している.

論争が思想の対立に直結し，ここまで生臭くなっ てしまうと, いささか辟易してしまうが, 地質学史 あるいは地球科学史上の事件として考える之, これ ほど興味深い論争も少ないであろう. 論争の決着は まだついていないが, 地理学の関係者もこういう論 
争があったということを知っておいた方がいいと思 う.ただここの部分を読みながら, 評者は, 論争と いうものがきわめて少ない地理学界の現状に照らし 合わせ，ついため息をついてしまった：なお第 1 部 では貝塚爽平が「大地形とプレートテクトニクス 一1930 1970 年ころの回顧—」を寄稿してい る.

第 2 部から第 4 部までは論文集で, 「活断層と地 震予知」,「テクトニクスと地震」,「南部フォッサマ グナ地域の地質と地震」の 3 つの部分に分け， 17 の論文が収録されている，学会誌風の論文もないわ けではないが, 全体としては本誌の特色を反映して 総説風の読みやすいものが多く, かなり程度の高い 内容の理解を助けてくれる. 大胆に仮説を提示した ものもあり，このこともこの雑誌ならではの特色と なっている，なおこの部分には地理学の関係者の寄 稿が多い．掲載順にあげてみると次のようである. 太田陽子, 平川一臣, 東郷正美, 今泉俊文, 上杉

陽, 池田安隆.

第 5 部は「思い出, など」と題し, 松田先生をめ ぐる先輩や友人, 後輩, 弟子, その他, 実に多彩な 人たちの思い出話や随想からなる，これもいうまで もなく，おもしろい，端正な紳士で，一見とりつき にくい先生の隠れたエピソードなどが紹介されてい る.ただ，先ほど論争の余波がところどころにうか がわれ，時々どきっとさせられることがある，なお この部分でも地形学者の寄稿が多い. 岡田篤正, 米 倉伸之, 中田 高, 山崎晴雄, 植村善博の各氏であ る.

月刊地球には，ほかにも『上田誠也教授退官記念 号』(号外, No. 3，1991）や，先年亡くなった中村 一明教授の追悼号（第 10 巻第 2 号，1988）がある. いずれも充実した内容であるのであわせて紹介して おきたい。

（小泉武栄）

松井 健 - 岡崎正規編著 : 環境土堹学一人間の 環境としての土壌学—— 朝倉書店, 1993 年 2 月, A5 判, 257 ページ, 図 106, 表 61, 3, 914 円.

地球規模の環境問題が騷がれはじめて, 多くの関 連書籍が発行されてきた．地球規模の環境問題を含 め, 環境問題のキーワードは水, 土, 緑の 3 つに集 約されると考えられる. 緑（植生あるいは生態系）
については数えきれないほどの書籍が店頭を埋めて いる．また，水についても環境を視点においたもの が発行され始めている. 今回出版された環境土壤学 は土壤をめぐる環境問題を広範に扱った最初のもの ではないかと考えられる。

まえがきにあるように，本書は人間環境としての 外界の一部である土㙵に関する内外の研究成果と今 後の課題を総括し, 展望したもので, “土袞環境 学”という学問分野を構築しようとする試みの第一 歩でもある。

本書は農学関係の 5 人の著者による合計 7 章から なる．簡単な目次と内容は次のようである，

1. 土壤学々環境土壌学

2.人間と土壤

3. 地形・地質之土壤

4. 都市と土壤

5. 土培之污染

6. 地球規模の環境破壊と土壤

7. 土㙥環境の保全管理

第 1 章の「土㙵学々環境土壌学」は, 「環境土壌 学とは」(松井 健) と「土壤の環境保全機能」(松 井）からなっている．環境土壌学を人間の生活・生 産の諸活動に及ぼす土壤の影響と, 人間の諸活動が 土壤に与える影響を研究する土壤学の分野と定義し 自然システムの1つとして土㙵系（ペドシステム） を提案している. 土壤系の環境保全機能として 10 機能（植物生産機能, 水質 - 污染物質浄化機能, 貯 水・透水機能，埋蔵文化財保存機能，アメ二ティ機 能, 自然教育 - 教材機能, 建造物支持機能, 土地施 設施工機能，建設資材機能，窯業原料機能）をあげ ているが，無理にこじつけているような気もする. この原因の 1 つに環境土䁃学が扱う土壤の定義がは っきりしていない点があるのではないかと考えられ る.

第 2 章の「人間と土壌」は, 「文明と土塞」(岡崎 正規),「食料生産の場としての土㙵」(陽 捷行), 「資源としての土壤」(鈴木創三)，「景観としての土 壤」(輿水 肇),「健康な生活のための土壤」(鈴 木）から構成されている. 土壤と人間のかかわり， 土壤学の基礎知識が盛り込まれている。この中で “土壤景観”という新しい研究分野を提案し，土壤 の存在を感じさせる風景と定義しているが, 景観の 構成要素として重要であるという認識で十分ではな いかと感じられてならない。 
第 3 章の「地形・地質之土㙵」では,「海岸低 地」(軖水), 「台地 - 丘陵地」(松井, 岡崎), 「山 地」（鈴木）を扱っている．主要な地形単位と土壤， あるいは開発・災害問題などが図表によりまとめら れている. 地形単位として沖積低地を取り上げるべ きではないかと思われる. ゴルフ場の問題が簡単に ふれられている.

第 4 章の「都市と土壌」は, 「都市生活亡土壌」 (輿水),「緑化基盤」(輿水),「都市化による污染」 （鈴木）からなっている. 都市の土壤を水分浸透能 亡有機物分解能から評価する視点は興味深く, 公園 のあり方などについても興味あるデータが示されて いる.

第 5 章の「土壤と污染」は，「重金属」(陽),「農 薬」(岡崎),「廃棄物と土壤」(岡崎) をテーマとし て取り上げている. 今後大きな問題となってくるで あろう土壤污染, 廃棄物問題が要領よくまとめられ ている. 欲をいえば, 最近の動向, 土壌污染と地下 水污染の関連などにもふれていただきたかった．

第 6 章の「地球規模の環境破壊之土壌」には, 「温暖化」(陽)，「オゾン層破壊」(陽),「放射性物 質による污染」(岡崎), 「酸性雨」(岡崎), 「砂漠 化」(岡崎), 「熱帯林の破壊」(松井) と話題のテー マを扱っている．地球規模の環境問題を要領よくま とめ, 読みやすい. ただ, 土壌とのかかわりについ てもう少し解説が欲しい気がする一章である.

第 7 章の「土猿環境の保全管理」では,「環境ア セスメント」(松井),「土壤のモニタリング」(陽),

\section{学 界消 息}

\section{本学会関係}

第 12 回常任委員会 3 月 27 日（土） 15 時 18 時, 学会事務所にて開催. 出席者 : 中村常任委員長, 青木, 小泉, 米倉の各常任委員, 滝沢会計専門委員 (大森常任委員の代理), 梅本庶務専門委員 (書記).

1. 入退会希望者について審議し, 入会正会員 4 名, 準会員から正会員への移行 5 名, 退会正会員 4 名（稲葉良彦, 滝野 實, 平井啓介, 三上正久）を 承認した。

2. 静岡大学の教官公募, 「古地震シンポジウ 厶」の案内等の地理学評論への掲載を承認した.

3. 春季学術大会での常任委員の役割分担を決め,
「環境管理計画と土壌」(舆水) を取り上げている. まとめあるいは総合的なアプローチとして，アセス メント，モニタリング，管理計画が検討されている。 全体を通読して環境土壌学ししての大きな枠組み, 視点がもう1つはっきりしないのは少々不満の残る ところである. 複数の著者が分担したためやむを得 ないのかもしれないが.

最近話題となっているほとんどの環境問題を取り 上げているといっていい程の内容を含んでいるが, これらの事象，現象について“土袞から，あるいは 土壤を通して何が読み取れるのか”あるいは, “土 壤をよ゙うみればよいのか”についてふれて欲しい気 がする．恐らく多くの読者は環境土壌学という夕イ トルからこのようなことを期待しているのではなか ろうか

また，全体として，内容は豊富である反面，図表 などの説明が不足しているあるいは物足りない感を 免れない箇所が散見されるのは残念である.

最近は過剰とも思えるほどの数の書籍が出版され ており，値段も必ずしも気軽に購入できるものばか りでもない，そうなると一冊の書籍の中に詰め込ま れた情報量之価格の関係が 1 つの判断材料になるで あろう.この面からは本書は新しい情報 (文献), データがかなり詰まっており，購入し，一読する価 値がある一冊と思われる，とくに，授業の種本，あ るいは教科書などとしても利用できると考えられる。

（田瀬則雄）
各種委員会の委員候補者の選定を行なった，

4. 会計専門委員会から「1992 年度一般会計収 支決算書」,「1993 年度一般会計予算案」が提出さ れ，内容について審議した。

5. 永年会員功労賞受賞候補者の選定基準修正案 を審議した。

6. 1993 年度評議員会の議事進行について打ち 合わせを行なった。

第 13 回編集専門委員会 4 月 10 日（土） 13 時 30 分〜18 時, 学会センタービル会議室にて開催. 出席者: 青木委員長, 大崎, 黑坂, 斉藤, 竹内, 田 瀬, 千葉, 手塚, 東郷, 徳永, 福原, 松倉, 山下の 各専門委員. 


\title{
1993 年度日本地理学会総会・春季学術大会および評議員会記事
}

\author{
（於・立正大学） \\ 大 会 経 過 \\ 4 月 1 日 (木) 14 時 00 分 16 時 30 分 \\ 評議員会 ( 1 号館第 7 会議室) \\ 4 月 2 日（金） 10 時 00 分 12 時 00 分 \\ 特別研究発表 (第 3 会場) \\ 9 時 20 分 12 時 00 分 \\ 一般研究発表 \\ 13 時 00 分 13 時 40 分 \\ 会長講演（石橋湛山記念講堂） \\ 13 時 40 分 15 時 10 分 \\ 総会 (石橋湛山記念講堂) \\ 15 時 15 分 17 時 45 分 \\ 18 時 00 分 20 時 00 分 \\ シンポジウム「大学再編成の中の地理学」 \\ (石橋湛山記念講堂) \\ 懇親会（大学食堂） \\ 4 月 3 日（土） 9 時 00 分 17 時 00 分 \\ 一般研究発表 \\ 13 時 00 分 15 時 00 分 \\ 特別研究発表（第 3 会場） \\ 13 時 00 分 17 時 00 分 \\ 研究・作業グループ \\ 総 会 記 録
}

4 月 2 日（金） 13 時 40 分〜 15 時 25 分, 立正大 学石橋湛山記念講堂にて開催. 浮田典良会長; 西川 治大会委員長の会場校挨拶の後, 議事.

議長 : 肥田 登会員 書記 : 竹内裕一庶務専門委員 出席正会員数（正会員 2,989 名中, 出席者 180 名, 委任状 1,025 名)

\section{I 報告事項}

1. 1992 年度事業報告

最初に中村和郎常任委員長より，下記の逝去会員 名が報告され，逝去された会員に黙禱が捧げられた．

逝去会員 : 名誉会員 ; 矢嶋仁吉, 幸田清喜, 正会 員 ; 内田安守, 増田政之, 松井武敏, 中田正己, 大 村 肇, 山口貞夫, 矢守一彦, 梅原正巳, 木村辰郎, 大原久和, 松下 進, 小寺廉吉, 池田善昭, 菊池一 雅, 筒浦 明, 大久保武彦の 18 名.

次に以下の各項目について報告があった．詳細は 評議員会記録（I -1.）を参照していただきたい.

1）会員数，2）出版刊行物について，3）集会に ついて.

4) 常任委員会・専門委員会: 本年度は, 学会事 務の電算化, 永年会員功労賞の設置, 大会予稿集の 定期購読制度の発足，社団法人化についての検討， 評議員に対する学会運営に関するアンケートの実施, 常任委員会主催のシンポジウムの開催などが行なわ れた。 5）各種委員会：a. 地理教育委員会 ; 常任委員会 に対し，地理教育を専門に担当する常任委員を おくことを提案した，b. 学会史編纂準備委員 会 ; 2000 年に『75 年史』, あるいは 1995 年に 『70 年史』を刊行することを提案した。『75 年 史』刊行の方向で検討中. c. 学会運営検討委員 会; 評議員選挙に関する答申（第 1 次）を提出 した.

6）研究・作業グループ：1992 年度は，4 作業グ ループ, 15 研究グループが活動を行なった.

7）他学会との交流 : 1992 年 8 月の IGU への参 加をはじめ, 研究集会等他学会との共催事業を 積極的に実施した。

2. 1992 年度決算報告

別紙として配布された資料に基づき，大森博雄会 計専門委員会委員長より, 収入・支出ともに順調に 行なわれていたとの報告があった。

\section{3. 監查報告}

足利健亮会計監査より帳簿・支出命令書なよ゙を検 討した結果, 会計が俁りなく施行されており, 正常 な運営である旨の監査報告がなされた。

以上は, 拍手多数で承認された.

4. 日本地理学会研究奨励賞受賞者の選考結果に ついて

1992 年度研究奨励賞受賞候補者選考委員会（河 
邊 宏委員長, 委員 8 名) は, 審議の結果, 次の 2 名を候補者として決定し, 評議員会で承認された。

長谷川裕彦:「北アルプス南西部, 打込谷の水河 地形々水河前進期」（地理学評論第 65 巻 (Ser. A) 第 4 号)

R. D. Schlunze: "Spatial Diffusion of Japanese Firms in West Germany and West Berlin from 1955 to 1985”「旧西ドイツにおける日本企業 の空間的拡散」(Geographical Review of Japan, Ser. B, Vol. 65, No. 1)

以上, 2 名は拍手で承認された.

5. 日本地理学会永年会員功労賞受賞者について 中村常任委員長より, 117 名の 1993 年度永年会 員功労賞受賞者の発表があった. 受賞者は以下の之 おり.

浅井辰郎, 浅香幸雄, 朝倉隆太郎, 浅間公介, 浅海 重夫, 有末武夫, 淡路正三, 安藤萬壽男, 伊倉退蔵, 池田雅美, 石井素介, 井関弘太郎, 伊勢田豊次, 市川健夫, 市毛陽二郎, 市川 勝, 稲永幸男, 位野木 壽一, 岩永 実, 岩本政教, 上島正徳, 上野福男, 氏家 武, 大久保武彦, 大角留吉, 大槻徳治, 小川 賢之輔, 奥村和夫, 織田武雄, 小沼常治, 尾原信彦, 籠瀬良明, 柏村一郎, 春日茂男, 加藤喜蔵, 金崎 肇, 兼子俊一, 川上健三, 神尾明正, 木内四郎兵衛, 木内信蔵, 菊地利夫, 菊地光秋, 喜多村俊夫, 木村 宏, 吉良竜夫, 桐野利彦, 小出武, 河野通博, 小林寛義, 小堀䉷, 近藤 廣, 榊原康男, 櫻井明俊, 佐藤甚次郎, 佐藤 久, 柴田孝夫, 清水馨八郎, 下村 数馬, 下村彦一, 水津一朗, 椙村大涁, 関 喜四郎, 関口 武, 宗田克己, 高橋俊示, 棚瀬善一, 谷 信勝, 谷岡武雄, 千葉徳爾, 辻 正雄, 辻田右左男, 筒浦 明, 坪内庄次, 手塚博禮, 土肥勇二郎, 戸谷 洋, 長岡安太郎, 中田栄二, 長津一郎, 中野尊正, 中野 弘, 西川 治, 西村嘉助, 橋本孝平, 服部信彦, 濱 英彦, 原田嘉兵衛, 福井英一郎, 福井武雄, 藤浪 武三, 船越謙策, 別技篤彦, 堀内義隆, 堀口友一, 増澤譲太郎, 町田 貞, 松井, 勇, 松田 孝, 松村 安一, 美河 納, 水山高幸, 村上節太郎, 村木定雄, 村田貞蔵, 百瀬有郎, 矢澤大二, 安田初雄, 䈃浦 進一, 山鹿誠次, 山口弥一郎, 山階芳正, 山本荘毅, 吉崎恵次, 吉田義信, 米倉二郎, 渡辺茂蔵 以上 (敬称略)

\section{6. 日本学術会議報告}

地理学研連代表の吉野正敏代表が欠席であったた
め, 中村常任委員長より吉野代表の書面による報告 (『オルビス』の刊行, IGCリージョナルコンファ レンスの開催予定, IGDP 関係等) が代読された。 また, 人文地理学研連の斎藤 功委員より秋に神戸 商科大学で「異文化理解」をテーマにシンポジウム を開催する予定である等の報告があった。

なお，以上の報告事項に対して次のような質問が あった。

1）予稿集が送られてくるのが遅れたこと.

2）巡検がないのはなぜか.

3）永年会員功労者に名前が上がっている人とそ うでない人がいるがなぜか.

これに対して，常任委員長より，1）予稿集の 定期購読制に伴う発送体制の変更，2）巡検参加 者の減少や会場校の都合等の理由があり, 巡検の 実施については今後検討していく，3）一定の基 準に基づいて選考したが, 選考基準も今後, 再検 討する余地がある旨の回答があった.

\section{II 審議事項}

1. 1993 年度事業計画 中村常任委員長より事業計画の提案があった. （詳細は評議員会記録（II-1，6，8）·参照）

以上は, 拍手多数で承認された.

2. 1993 年度予算案

大森会計委員会委員長より別紙として配布された 資料に基づき，予算案の説明がなされた.

以上は, 拍手多数で承認された.

3. 名誉会員の推薦

中村常任委員長より名誉会員候補者推薦委員会の 答申を踏まえ, 市川正巳君を名誉会員に推挙する提 案がなされた, 拍手多数で承認された.

以上の審議事項の後, 次のような要望や意見が出 された。

1）学会の発表時間が短すぎる. 発表方法につい て検討してほしい.

2）複数の研究・作業グループに参加したいが, 時間的に一斉開催で参加できない，方法はない か.

3）評議員会の活動を一般会員はほとんど知らな い. アンケート結果を公表する場合は, 名前も 明らかにしてほしい。

これに対して，常任委員会より，1）については 検討する. 2) については他の委員会等の開催もし なければならず, 今後検討課題としたい，3）アン 
ケートは基本的に無記名で行なわれたので名前を明 らかにできない，回収率が悪いが，まだ集計中なの で評議員の方は回答を寄せてほしい等の回答があっ た.
引き続き表彰に移り, 市川正巳新名誉会員の表彰, 長谷川裕彦・R. D. Schlunze 両会員への研究奨励 賞の授与, 永年会員功労賞受賞者代表の村木定雄 · 山口弥一郎両会員への表彰が行なわれた:

\section{評議員会記 録}

4 月 1 日（木） 14 時 17 時 15 分，立正大学 1 号館第 7 会議室にて開催. 浮田典良会長の挨拶に続 いて, 新井 正会員より会場校挨拶が行なわれた. 出席者 31 名 (最終的には 36 名), 委任状 6 名で評議 員会の成立が確認された後, 議事. 議長 : 森川 洋 評議員 書記 : 加賀美雅弘庶務専門委員

\section{I 報告事項}

1. 1992 年度事業報告および事務報告

小泉武栄庶務専門委員会委員長より, 配布資料に 基づき以下の報告が行なわれた。

1）会員動静：1993 年 3 月 1 日現在, 会員総数は 3, 054 名（名誉会員 23 名, 正会員 2,989 名, 準会員 42 名)である.

2）逝去会員: 名誉会員 2 名, 正会員 16 名が逝去 された。

3) 出版刊行物 : 地理学評論 Ser. A 12 冊 832 ペ ージ, Geographical Review of Japan, Ser. B 2 冊 150 ページ, 学術大会予稿集 2 冊 562 ページ, 巡検案内（予稿集抜刷） 4 冊を刊行し た。

4) 集会: 春季学術大会および総会（中央大学： 参加者約 740 名), 秋季学術大会 (東北大学, 東北地理学会之共催 : 参加者約 520 名) を開催 した.

5）役員会: 評議員会 2 回, 常任委員会 12 回を開 催した。

6）専門委員会報告

（1）庶務専門委員会：a. 文書の受け取りと発信, 各種の委員会との連絡・調整, “常任委員会・評 議員会・総会の記録作成, 寄贈図書類の受け入 れと整理を行なった，また，学会事務電算化を 進め, 予稿集の定期購読制度を発足させた。

b. 永年会員功労賞受賞候補者の選定を行なっ た. c. 学会運営検討委員会を発足させ, 選挙制 度の見直し, 日本地理学会の社団法人化の是非 等の検討を依頼した。d. 会員制度改正の原案 を作成し, それに伴う会則や役員選挙規定の改 正案を作成した. e. 次の会員名簿から会員の專
門分野や関心分野を記載することとし，そのた めの準備とアンケートを行なった.

(2) 編集専門委員会: 地理学評論第 65 巻 (Ser. A）第 4 号〜第 66 巻第 3 号に掲載された原稿 は, 論説 25 編（前年度 24 編）, 短報 5 編（前 年度 13 編), 展望 1 編（前年度 5 編），書評 ・ 紹介 15 編 (前年度 17 編), 紙碑 6 編（前年度 2 編), および 1992 年度 IGC 大会記事, 学会関 係記事などであり, 総ページ数は 832 (前年度 935 ページ) であった（前年度あった会長講演, 資料各 1 編は本年度はなし)。また，特定のテ 一マを取り上げた特集号はなかった，掲載論文 は, 自然地理学関連 7 編, 人文地理学関連 24 編よりなり, 例年にくらべて著しく人文地理学 に偏する結果となった．年度中に新規投稿され， かつ審査された論文は 34 編（前年度 53 編）で あったが，これは 1992 年後半の投稿が比較的 少なかったことに原因がある，なお，各論文の 巻頭に目次, 日本語キーワードを揭載すること を検討中である.

（3）集会専門委員会：1992 年 10 月の秋季大会 (東北大学にて東北地理学会と共催) および 1993 年 4 月の春季学術大会 (立正大学) のた めの準備などを行なった. 1992 年秋季学術大 会では 5 つのシンポジウムが行なわれ，1993 年春季学術大会では常任委員会主催のシンポジ ウムや特別研究発表など新たな企画が実施され ることになった. しかし 1993 年春季学術大会 では巡検を行なうことができず，巡検のあり方 については今後の検討課題とされた.

（4）会計専門委員会 : 会費の徵収および予算執行 にかかわる事務を行なった．学会事務会計処理 のための電算化拡充計画に基づき, パーソナル コンピュータを購入した。 大会予稿集の印刷部 数および販売部数の安定化によるリスク削減の ために購入予約制度を導入した. 1993 年 3 月 に, 1992 年度の決算と 1993 年度の予算案の編 成を行なった，その他，1992 年度会費納入の 
督促状を 7 月と 12 月に発送し，3 月には 1993 年度の除籍対象者への会費納入の最終督促状を 発送した。

（5）企画専門委員会：a. 前委員会が決定した学 会シンボルマークの具体的な使用方法について 検討した. b. 1994 年度からの高等学校学習指 導要領の改訂に伴う 1997 年以降の大学入試セ ンター試験科目に関して, 文部省と大学入試セ ンターへ要望書を出すとともに, 86 の関連学 会へ協力を呼びかけた. c. 日本地理学会の会員 制度を検討した. d. 日本地理学会の社団法人 化を検討し，それに関する情報・資料を収集し た. e. 地理教育の振興のための資料収集を行な う一方, 地理教育検討委員会との連絡を保った f. 会員の研究奨励のための方策として, 研究費 補助や学会賞の新設を含めて検討した．g.日 本地理学会評議員へのアンケートの原案を検討 した.

（6）渉外専門委員会: 通常の業務を遂行した.

（7）欧文機関誌編集専門委員会：今年度は, 第 65 巻第 1 号を論説 3 編, 短報 2 編で編集し, 第 65 巻第 2 号を論説 3 編, 短報 1 編で編集した。

7）各種委員会報告

（1）名誉会員候補者推薦委員会：1名を名誉会員 候補者として推薦することとした。

（2）1992年度研究奨励賞受賞候補者選考委員 会 : 1992 年度受賞候補者 2 名を決定した.

（3）地理教育委員会：報告参照.

（4）学会史編纂準備委員会: 報告参照.

（5）学会運営検討委員会：答申参照.

（6）国立地図学博物館設立推進委員会：報告参照.

（7）研究・作業グループ報告： 4 作業グループ,

15 研究グループが活動した.

（8）他学会との交流：8 件のシンポジウムを共 催・後援した。

以上は報告どおり承認された。

2. 1992 年度決算報告および監查報告

大森博雄会計専門委員会委員長より配布資料に基 づき報告がなされた。これに対し，足利健亮会計監 査より監査の結果適切な会計処理がなされていたと の報告があった，決算報告は報告じおり承認された.

3. 研究・作業グループの発足

新しく発足した研究・作業グループについて，報 告があった
4. 日本学術会議報告

日本学術会議関係について報告があった。

5. その他

田林 明企画専門委員会委員長より，すでに実施 した評議員対象のアンケートの結果について報告が あった。 なお，その公表の是非について審議するこ ととした.

\section{II 審議事項}

1. 1993 年度事業計画

中村和郎常任委員長より役員会, 各種委員会, 研 究・作業グループ, 集会, 出版刊行, 関連学会およ び学術団体との交流・協力について計画案が提案さ れた。このうち, 集会では, 今年度の秋季学術大会 を立命館大学で開催（10月 10 日〜11日）を予定 していることが報告された。 以上の 1993 年度事業 計画案は, 原案よ゙おり承認された。

\section{1993 年度予算案}

大森博雄会計專門委員会委員長より資料に基づき 提案があり，若干の修正・検討を要する点はあった がおおむ权原案じおり承認された。

3. 名誉会員の推薦について

市川正巳君が原案よ゙おり承認された。

4. 日本地理学会研究奨励賞受賞候補者の選考結 果について

長谷川裕彦, R. D. Schlunze 両会員が原案じお り承認された。

5. 日本地理学会永年会員功労賞受賞候補者につ いて

資料に基づき 117 名の永年会員功労賞受賞候補者 が提案され, 若干の誤字訂正のうえ, 原案どおり承 認された。なお, 選考規定の付帯事項について, 満 年齢 80 歳以上の会員については会員歴 20 年で候 補者にしたいという提案があり，提案どおり承認さ れた。

6. 各種委員会の設置および委員の委嘱について 資料に基づき 7 つの委員会（名誉会員候補者推薦 委員会, 地理教育委員会, 学会史編纂準備委員会, 地図博設立推進委員会, 学会運営検討委員会, 研究 奨励賞受賞候補者選考委員会, 選挙管理委員会) の 設置が提案され，委員の委嘱もあわせて原案どおり 承認された。委嘱委員名は次の上おり. 研究奨励賞 受賞候補者選考委員会: 門村 浩, 応地利明, 大和田 道雄, 金安岩男, 小疇 尚, 鈴木冨志郎, 高橋伸夫, 肥田 登, 宮口侗廸. 選挙管理委員会 : 藤田直晴, 
内山幸久, 小林正夫, 島津俊之, 杉谷 隆, 土谷敏治, 長谷川 均, 水嶋一雄, 山本, 充.

7. 会員の除籍について

資料に基づき 23 名の除籍対象者が示された。こ のまま会費の納入がないと半年後には除籍となるの

で, 会費の納入を勧める旨の提案がなされ，原案ざ おり承認された.

8. その他

1) 戸所 隆評議員より, 指定統計等官庁統計の 内容および利用の改善に関する委員会の設置に ついての提案があり, 審議の結果, 設置に向け て検討することとした。

2) 小野有五評議員より, 高校地理教科書と大学 入試の改善を考える委員会の設置についての提 案があり,審議の結果, 地理教育委員会に小委員 会を設けるような形で，具体的に検討すること とした，また, 同評議員より，学術大会の発表形 式についてこれを改善するべきとの提案があり， 審議の結果, 集会専門委員会で検討すること之 した．なお，会員の意見を表明する場として，地 理学評論に『フォーラム』のような投稿欄を設
ける方向で編集専門委員会で検討することとした。

3）田林 明企画專門委員会委員長より出された 評議員対象のアンケートの結果の公表の是非に ついての審議を行ない，アンケートを企画委員 会で整理したうえで地理学評論に公表すること とした.

\section{III その他}

小泉武栄庶務専門委員会委員長より, 資料に基づ き, 正会員の所属構成之会員数の動向, 関連学会に おける若手研究者の割引状況, 学会の社団法人化に ついての説明がなされた．また，地方区の廃止など 選挙制度の見直しについて検討中であることが報告 された。

出席者: 青木栄一, 青木伸好, 足利健亮, 新井 正, 石原 潤, 市川健夫, 伊藤安男, 太田陽子, 大森 博雄, 小口 高, 奥野隆史, 小野有五, 金田章裕, 日下雅義, 小疇 尚, 小泉武栄, 小林健太郎, 斎藤 功, 設楽 寛, 鈴木隆介, 竹内啓一, 田林 明, 田村 俊和, 戸所 隆, 中村和郎, 西川 治, 野沢秀樹, 肥田 登, 水見山幸夫, 深石一夫, 正井泰夫, 村上 誠, 森川 洋, 吉越昭久, 吉野正敏, 米倉伸之

\section{名誉会員候補者推薦委員会答申}

\section{名誉会員候補者推䳡委員会}

\section{委員長 奥野隆史}

名誉会員候補者推薦委員会は, 1992 年 10 月 10 日に会議を行なった，選考基準にのっとり慎重に検 討した結果，下記の会員を付記の推薦理由により， 委員会全員の一致した意見として, 名誉会員候補者 として推蔗することを決定した，なお，当委員会に おける審議の過程でまとまった付帯意見を末尾に記 した.

\section{名誉会員候補者 : 市川正巳君}

推萀理由: 市川正巳君は永年にわたって地理学, とくに地形学, 水文学の研究, 教育に努め, 1992 年末までに学術図書 23 編, 論文 93 編におよぶ注目 すべき業績を挙げた。

同君は土壤侵食, 山地崩壊之地滑り, 河床物質之 平衡勾配, 斜面形の発達過程, 地形亡地下水, 地下 水の賦存量, 流域の水収支, 水資源, 都市水文学, とくに都市化に伴う水文循環過程の変化, 砂漠化お よび酸性雨など多方面にわたるテーマを取り上げ, また地理学評論に 16 編を投稿し, その内 9 編は論 説，総合報告であるなど顕著な成果を得ている，筑
波研究学園都市の流出過程の変化に関する研究は日 本における都市水文学的研究の㜴矢として高く評価 された，その骨子は『水文学の基礎』(1973)，『日 本の水収支』(1978), 『水文学』（1990）に集約され ている.

同君は東京教育大学, 立正大学, 筑波大学, 兵庫 教育大学, 秋草学園短期大学なら゙で教育と研究に従 事し, 筑波大学, 兵庫教育大学, 秋草学園短期大学 では副学長として学術行政にも貢献した.さらに, 熊本大学, 広島大学, お茶の水女子大学, 東京大学, 立正大学にて非常勤講師を勤め, 幾多の後進の育成 に努力され, 斯学の振興に寄与した。 また, 1978 年から 1985 年まで日本学術会議会員に選出され, その間, 地理学研究連絡委員会委員長として活躍し, 国際地理学会議の日本招致に成功し, その組織委員 会委員として, また数次にわたり, 国際地理学会, 国際水資源学会に日本代表として出席し, わが国の 国際的地位の向上に尽力した.

同君は1917 (大正 6) 年生まれで, 日本地理学 会会員歴は 40 年を越え, その間, 評議員を 8 期, 常任委員を 2 期, 常任委員長を 1 期勤め, 1982 年 
から 1983 年にかけては会長に選出され，学会の運 営に貢献された。

以上により, 市川正巳君を本会の名誉会員として 推薦する。

付帯意見

当委員会は，日本地理学会名誉会員選考規定に基 づいて表記の会員を名誉会員候補者として推薦した が，この規定に記されている選考基準第 2 項「本会 に対して，特に貢献のあった者」に関して明確さに
欠ける点がうかがわ机る。この条文は，本学会にお ける役員歴を意味すると解されるが，役員の範疇が 多数あり, かつその間に学会に対する貢献度の軽重 が存在することは明らかである。この軽重の評価に 主観が入り，このことが選考を困難ならしめる一因 となっている，選考基準第 3 項にみられるような客 観的な基準に改められることが望ましいと考えられ る. 当委員会の審議過程においては会長および常任 委員長の経験者に限定するという意見が出された.

\section{研究奨励賞受賞候補者選考委員会答申}

1992 年度研究奨励賞受賞候補者選考委員会

\section{委員長 河邊 宏}

1992 年 1 月から 1992 年 12 月までに出版された 地理学評論 Series A および Series B に揭載され た該当論文 25 編について慎重に選考した結果，次 の 2 君を受賞候補者とすることに決定したので，選 考理由を付してここに答申する.

研究奨励賞受賞候補者 : 長谷川裕彦君

「北アルプス南西部, 打込谷の水河地形と水河前 進期」(地理学評論第 65 巻 (Ser. A) 第 4 号)

本論文は, 綿密な空中写真判読と現地調査により, 北アルプス笠ケ岳北面の打込谷の水河地形を詳細に 分類・記載し，水河地形発達史を明らかにしたもの である。

時代決定資料の乏しい高山において，着実な現地 調査を重ねた結果モレーンを覆う指標テフラ(AT) を見出して氷河前進期の時代決定の手がかりを得, これに基づいて最終水期における前半に 1 回, 後半 に 3 回の, 計 4 回の水河前進期を復元した点が, 本 研究の特筆すべき成果である．同様の手法による調 査研究を継続することによって，わが国における水 河地形の特徴を明確化し，その発達史の絶対年代に よる編年の確立が期待できる．将来の発展性を高く 評価した.
研究奨励賞受賞候補者 : R. D. Schlunze 君

"Spatial Diffusion of Japanese Firms in West Germany and West Berlin from 1955 to 1985" (Geographical Review of Japan, Vol. 65, Ser. B, No. 1)

本論文は，旧西ドイツにおける 35 年間にわたる 日本企業の立地行動を, 旧西ドイッの経済の中心の 北から南への移動を背景に, 国際化が進むなかで進 出した日本側からの事情も踏まえて分析したもので ある。

デュッセルドルフへの集中から拡散段階に入ると ともに，その拡散プロセスは複数のイノベーション 中心地からそれぞれ異なった時期に，また業種によ って異なった形で行なわれることを見出し，その説 明のために非線形重力型多重回帰モデルが援用され た. その結果, 日本企業立地の拡散プロセス要因と して, 日本企業の情報ネットワーク，デュッセルド ルフからの距離, 都市システムにおける都市の中心 性が重要であることが明らかにされた。

企業立地という経済行動を，旧西ドイツ側の十分 な文献サーベイと統計資料の利用，日本企業の海外 投資戦略との関連で分析するなど広い視野で分析し た点，ならびに，その充実した論文内容である点が 評価される。

\section{学会運営検討委員会答申}

学会運営検討委員会

委員長 太田 勇

本委員会は 1992 年 10 月に発足し, 10 月 10 日, 12 月 19 日および 1993 年 2 月 13 日の 3 回, 委員会 を開催した，先に諮問を受けた事項のうち，評議員 選挙に関して下記のとおり第 1 回の答申を行なう.
評議員選挙に関する答申（第 1 次）

結論 I : 現行の地方区は廃止することが望ましい， ただし，それには過渡的な段階を考慮することが必 要と思われる。

廃止の基本的理由

現在, 日本地理学会は全国的組織として発展, 活 動しており，すでに地域の個別条件を勘案して学会 
活動を行なう段階ではなくなった，評議員は広い視 野で学会発展のために貢献してきたのが実状である. また, 大多数の学会員は評議員個人に対する学識や 行動に期待して投票に臨んでおり，全国区・地方区 の別を優先させる意識があるとはいい難い. 現状に おいて地方区の存在がとくに必要之判断できる材料 は見あたらない。

\section{現状の理解}

上記の結論を得るに至る過程で, 次の論議があっ たことを付記する.

1）評議員選出の地域的偏りに対する問題

評議員選挙に対する学会員の投票行動には, 地方 区を設置しなくても東京ないし関東地方への役員集 中を避ける傾向がうかがえる. それは，地方区当選 者の半数が, 全国区でも当選する票数を得ているこ とから判断できる. 現行地方区制度の廃止が，ただ ちに東京とその周辺地域のみへの集中を生むとは思 えない.

\section{2）当選者の獲得票数の不公平}

他方, 現在の地方区当選者のなかには, 獲得票数 が極端に少ない者が含まれている，この現実は有権 者 1 票の重さを著しく不公平にするものであり, 投 票者の立場への配慮を欠いている. 会員の地域的分 布と, 学会運営役員・委員として活動し得る人の分 布を考慮す机ば, 現行地方区制度の存続は不合理で
ある.

\section{3）地方区残存の根拠}

今日なお地域によっては, 当学会の会員・非会員 を問わず地理学者の活動をとりまとめる何らかの機 能が存在していると思われる. この点を勘案すると， 地方区の即時全廃は躊躇される.

実際の対応

廃止の方法に関しては, 即時全面廃止之段階的廃 止の意見が並立し，合意が得られなかった．段階的 廃止論では, 当面各地方区の定員を半減させ 1 とす る案が有力であった.

また，地方区に代わる新たな選挙区（たとえば， 地理教育分野など, 学会活動の機能を配慮した区 分）の設置は, 早急に結論が出せないとの意見が強 く, 継続審議となった.

結論 II : 評議員の連続就任期間は, 現行より 1 期 減少させ, 3 期 6 年とすることが望ましい. 1 期 2 年の間をおいた後は再選を認める。

\section{基本的理由}

会員から幅広く適任者が選べる条件を作り，あわ せて一部会員への適度の負担を軽減する必要がある. ただし, 現状で 2 期 4 年とすると, 学会運営の継続 性に問題が生じる恐机があるので, 上記の期間が適 切であると判断した。

\section{学術大会記 事}

1993 年度春季学術大会は, 4 月 2 日 (金) ・ 3 日 （土）の両日, 立正大学において開催され, 約 840 名の参加者があり, 盛会裡に終了した.

大会は 4 月 1 日 (木) 評議員会, 2 日 (金) シン ポジウム, 2 日 (金)・3日（土）両日, 一般研究 発表（ポスター・ビデオセッションを含む）が 6 会 場において, また特別研究発表が開催された。 3 日 （土）には研究・作業グループの集会が開かれた. また, 会長講演と総会は 2 日午後に石橋湛山講堂
において，懇親会は2 日夕方から立正大学食堂にお いて, 立正大学学長の御出席を得て開かれ, 210 名 余の会員がなごやかな懇談の時を過ごした.

立正大学の大会実行委員の諸会員, ならびに院 生・学生諸君には, 大会運営にあたって多大なご協 力をいただいたことに，深く感謝を表するものであ る. 各会場で座長の労をとられた会員に対して, 心 からお礼申し上げる. 


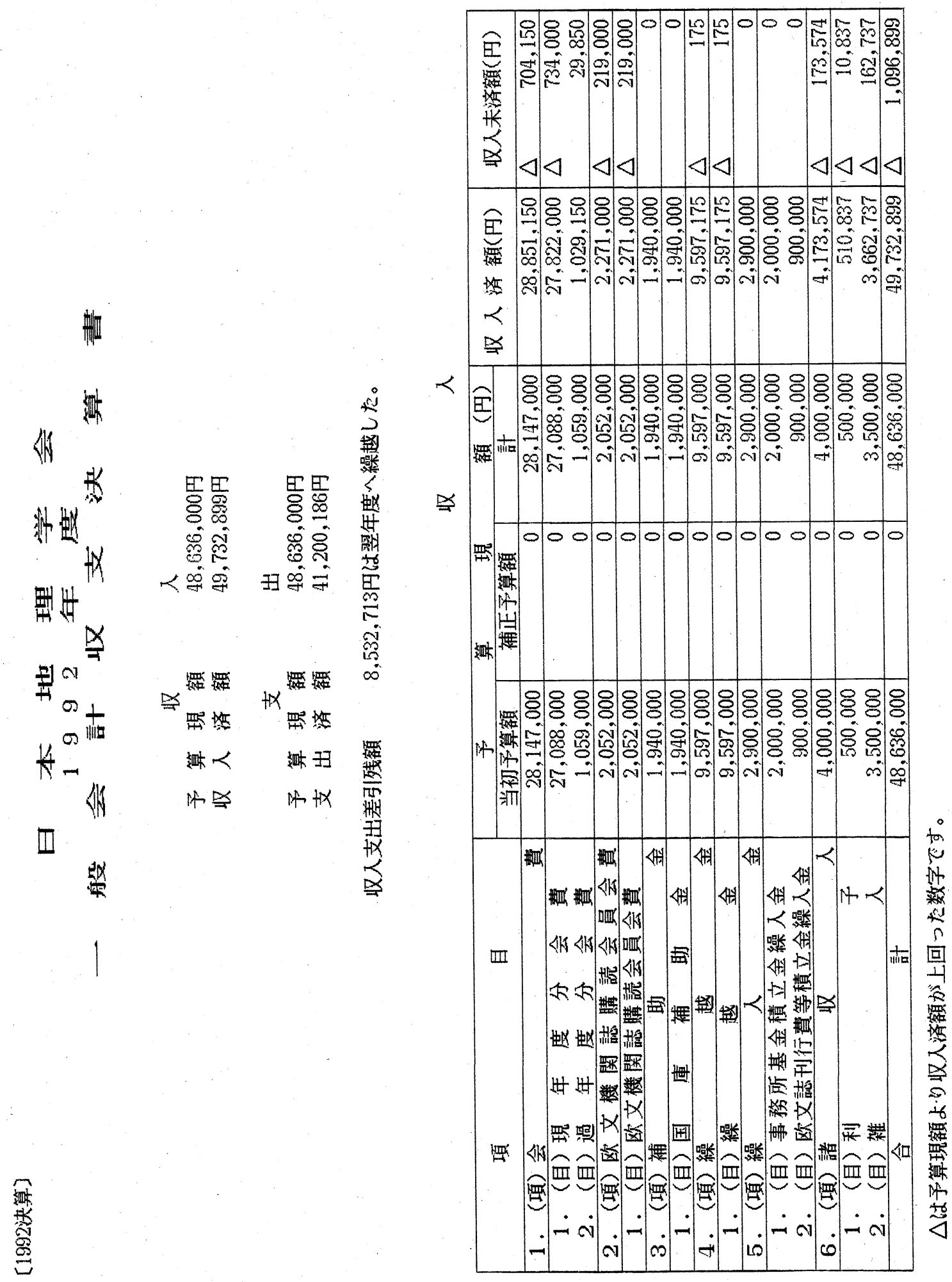




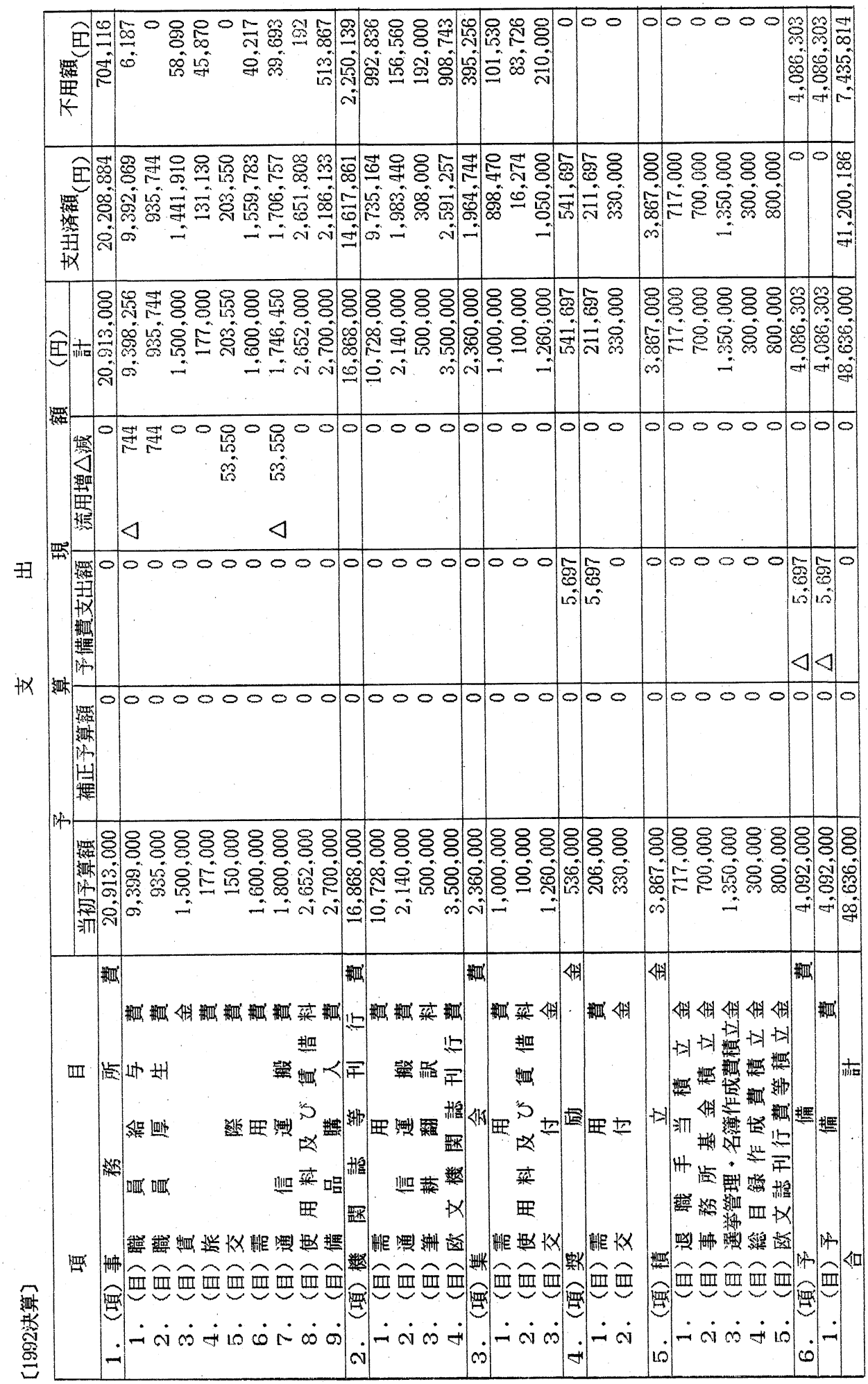




\section{会告 \\ 1993 年度秋季学術大会のお知らせ（第 2 報）}

1993 年度の日本地理学会秋季学術大会は, 下記のとおり立命館大学にて開催されることになりましたので, お知らせいたします。

1. 期 日 1993 年 10 月 10 日（日）～10月 11日（月）(ただし, 評議員会は10月9日（土）

2. 会 場 立命館大学 京都府京都市北区等持院北町 56-1

3.'連絡先 干603 京都府京都市北区等持院北町 56-1

立命館大学文学部地理学教室 電話 075-465-1111 内線 2458

FAX 075-465-8296（直通）

4. 日 程 10 月 9 日（土）評議員会

10 月 10 日（日） シンポジウム, 一般研究発表, ポスターセッション, 䅰親会

10 月 11 日（月） シンポジウム, 一般研究発表, ポスターセッション, 研究・作業グループ

5. シンポジゥム発表の申し込みと予稿集版下原稿の送付

シンポジウムで発表を希望される方は，シンポジウムに関する会告（本号）にしたがって，6月 20 日（土） までに各シンポジウムの責任者（オーガナイザー）に申し込んで下さい．シンポジウム発表者は責任者から送 付される予稿集版下用紙（本号巻末の版下用紙と同じもの）で原稿を作成し，発表申し込み用紙 A・B 片を 添付のうえ，オーガナイザーから指定される期日までにオーガナイザーあてにお送り下さい．

\section{6.一般研究発表の申し込み}

1) 発表希望者は, 本号巻末に綴じ込んである予稿集版下用紙を用いて原稿を作成し，発表申し込み用紙 $\mathrm{A} \cdot \mathrm{B}$ 片と版下原稿とそのコピー 2 部を添えて，7 月15 日（木）必着で日本地理学会集会専門委員会あてに お送り下さい，予稿集版下原稿の受理をもって発表申し込みとします。

2) ポスター（ビデオ・コンピュータ）セッション

希望者は 1）之同様に, 巻末の版下用紙を用いて, 期日までに版下原稿をお送り下さい. 予稿集版下原稿の 受理をもって発表申し込みとします. 会場にかぎりがありますので, 発表希望者多数の場合は, 先着順といた します.なお, ビデオ・コンピュータセッションで使用する機器は, 発表者のほうでご準備下さい.

3）一般研究発表の数は口頭発表者一人について 1 演題とします. シンポジウムおよびポスターセッション での発表との重複はかまいません。

4）発表演題ごとに発表時間帯を定めます. 発表時間帯を固定しますので, 発表時間を厳守して下さい. 詳 細は地理学評論あるいは予稿集に揭載されるプログラムを参照して下さい.

\section{7. 予稿集版下原稿の作成と送付について}

予稿集版下原稿は版下用紙を用いて黒インクで清書して下さい，ワープロで原稿を作成する場合も，必ず版 下用紙を用いて, 下記のいずれかの方法によって, 鮮明で濃い原稿を作成して下さい, 字や行の間隔を版下用 紙の升目にあわせる必要はありませんが, ページ枠とタイトル位置を厳守し, 読みやすい大きさの文字にして 下さい.フロッピー・ディスクは送付しないで下さい.

方法 1 : プリンター出力用紙のコピーをとり, 版下用紙の規定枠内に切り貼りします. 裏面は全面糊付けし て下さい.

方法 2 : プリンター出力用紙を白紙の台紙に切り貼りし，これから版下用紙の上にコピーをとります. 台紙 には版下用紙の枠を鉛筆で書き写して，位置をあわせるようにします.

予稿集版下原稿に本号巻末の発表申し込み用紙 A・B 片と版下原稿コピー2 部を添えて, 7 月 15 日（木） 必着で, 日本地理学会集会専門委員会に送付して下さい. 締め切りの直後にプログラムの作成, 予稿集の編集 を行ないますので, 締切日を厳守して下さい. 


\section{8. 研究・作業グループの会場申し込み}

研究・作業グループの集会は原則として 10 月 11 日（月）に開催するようお願いいたします．大会時に会 場使用を希望するグループは, グループ名, 責任者名, 連絡先, 開催希望時間, 参加見込み者数などを, 文書 で日本地理学会集会専門委員会あてに 7 月 15 日（木）までに申し込んで下さい. 会場の都合で開催時間など について希望に応じられない場合がありますので, あらかじめご了承下さい，

なお，予稿集・地理学評論に発表題目などを掲載希望のグループは，必ず 7 月 15 日（木）までにお申し込 み下さい.

\section{9. 宿泊施設について}

宿泊施設の斡旋は行ないません，大会前後は観光シーズンでもありますので，早めに各自でご予約下さい．

\section{3 年度秋季学術大会におけるシンポジウム報告者の公募について}

1993 年度秋季学術大会 (立命館大学にて 10 月 10 日〜11 日に開催) では, 下記のようなシンポジウムが予 定されています，発表を希望される会員は，6月20日（土）までに，氏名，連絡先，題目之報告内容の概要 （200 字〜 400 字）を希望するシンポジウムの連絡先にお送り下さい. 発表の採否・発表時間・予稿集版下原 稿の提出締切日・オーガナイザーからの要望などについては, シンポジウムのオーガナイザーから後日連絡い たします.

テーマ:リゾート開発と農山漁村

オーガナイザー : 石原照敏（岡山大）

趣 旨: 本シンポジウムは, 日本地理学会「リゾート開発と地域整備」研究グループの 3 年間にわたる研究成 果を総括し, 今後の研究の課題や方向を探ろうとするものである.

「リゾート開発」によって，環境問題が激化したために，リゾート開発そのものが毛嫌いされている風潮も ないではない，また，リゾートが，あってもなくてもよい単なる㜀楽くらいにしか考えられていないためか， リゾートの研究は基幹産業の研究と比べて重要ではないとさえ考えられているきらいもみられる．せっかく進 められているリゾートの研究も，現象の単なる追認に終わっているものも少なくない状況によどまっている.

しかし, リゾートの研究が, 等閑に伏されてよいであろうか.「過労死」さえも社会問題化している都市か ら，一時的にでも離れて，自然環境に恵まれた農山漁村などに滞在して心身のリフレッシュを図るために，社 会的には基本的人権としての「休養権」の確立が不可欠になってきているからである．また，過疎化に悩む農 山漁村ではリゾート産業の振興が急務となっているところが少なくないからでもある.

そこで, リゾート開発と地域整備研究グループは，環境保全に配慮しながら，農林水産業之共存し，相互に 発展しつつあるリゾート開発の事例研究を推進し，あるべきリゾート開発を模索してきた．その結果，環境保 全に配慮し, 既存の農林水産業との共存・相互発展を図るためには, リゾート開発と自然環境や集落との調和, 地域と調和したリゾート産業の業種・規模, リゾート産業之既存の農林水産業との土地利用・水域利用の調整, その地域区分などのあり方について研究することがいかに重要であるかわかってきた.

本シンポジウムは, 以上のような趣旨に基づいて, リゾート開発と農山漁村とのかかわりにういて研究し, あるべきリゾート開発と農山漁村との連関・共存・相互発展の地域システムの研究に接近しょうとするもので ある.

連絡先 : T700 岡山市津島中 2-1-1 岡山大学教養部 石原照敏 電 話 0862-52-1111 内線 920

FAX 0862-52-1442

\section{テーマ: 先史・歴史時代の気候変動}

オーガナイザー : 安田喜憲（国際日本文化研究センター）

趣 旨: 本シンポジウムは堆積物中の花粉や珪藻などの微化石分析による気候変動の復元, 年輪の解析や年輪 の酸素・炭素同位体比測定による気候変動の復元, 氷床の炭素・酸素同位体測定による気候変動の復元, ダス トによる気候変動の復元, 微地形の解析による気候変動の復元, 古記録による気候変動の復元, 火山噴火が気 候変動に与える影響, 人類の大気污染が気候変動に与える影響などについての研究成果を公募し, そうした気 
候変動が文明の盛衰や歴史の転換にいかなる影響を与えたかを総合的に考察することを目的としている.

連絡先 : 个610-11 京都市西京区大枝山 3-2 国際日本文化研究センター 安田喜憲 電 話 075-335-2150

FAX 075-335-2090

\section{自然災害と環境の地形学作業グループ 1993 年度第 2 回例会のお知らせ}

1. 日 時 6 月 5 日 (土) 14 時 17 時

2. 会 場 早稲田大学教育学部 (16 号館) 512 教室 (JR 高田馬場駅前より学バス利用, 「西早稲田」下車)

3. 発 表 小野有五 (北海道大) : 環境地理学からみた千歳川放水路計画の問題点

中山正民（早稲田大）：安倍川谷底平野および扇状地の特性と関連事象——駿府とその周辺地域

の開発と洪水について

4. 問い合わせ先 早稲田大学 大矢雅彦 電話 03-3208-2452

リゾート開発と地域整備研究グループ第 8 回例会のお知らせ

1. 日 時 6 月 26 日.(土) 15 時 30 分〜

2. 会 場 近畿大学本館 3 階 第 3 会議室

近鉄大阪線長瀬駅から東へ徒歩 8 分, 近鉄奈良線八戸ノ里駅から南へ徒歩 15 分（両駅とも普通 のみ停車)

3. 共 催 経済地理学会関西支部

4. 発 表, 石井雄二（阪南大）：畜産資源の活用による農村型リゾート開発の可能性について一一長野県信 州新町のめん羊振興の事例-

\section{古気候復元研究グループ 1993 年度第 1 回例会のお知らせ}

1. 日 時 7 月 3 日（土） 13 時 16 時

2. 会 場 山梨大学教育学部 $\mathrm{K} 301$

3. 発 表 吉村 稔 (山梨大) ・三上岳彦（東京都立大）：歴史天候データベースの現状と世界のデー夕整備 について

4. その他 発表後, 希望者に歴史天候データベースの検索等の練習をします.

5 . 連絡先 $\bar{\top} 400$ 甲府市武田 4-4-37 山梨大学教育学部地理学教室 吉村 稔 当日は休学日のため内線電話は通じません.

\section{地籍図類による景観復原研究グループ第 4 回例会のお知らせ}

下記の通り例会を開催いたします. 多数ご参加下さい.

1. 日 時 7 月 3 日（土） 13 時 30 分 16 時 30 分

2 . 場 所 佛教大学 1 号館 5 階大会議室

京都市北区柴野北花ノ坊町 96 電話 075-491-2141

3. 発 表 矢田 勝 (静岡県埋蔵文化財調查研究所): 静岡平野 (安倍川左岸) の表層条里型地割之発掘に よって判明した埋没条里型地割（平安初期に埋没）との比較検討

田中欣治 (三重短大) : 茂木亀六の土地丈量絵と彼の事跡

塚田利和（土地家屋調查士）：地番境界線之地理学上の境界線

4. 交 通 京都市バス「千本北大路」下車, 北へ徒歩 3 分で佛教大学. 千本北大路 (千北) へは (1) JR 京 都駅一(地下鉄 13 分)一北大路駅一(市バス 8 分)一千北. (2) JR 京都駅一市バス鳥丸ロバスター ミナル「B4」から乗車一（市バス 40 分) 一千北. (3) J R 二条駅一(市バス 15 分)一千北. (4)阪 急四条大宫駅一(市バス 20 分)一千北. (5)京阪三条駅一(市バス 25 分)一千北.

5. その他 ご照会は上記大学電話の内線 3061 桑原研究室にして下さい. 


\section{第 40 回風に関するシンポジウム（共催）講演募集のお知らせ}

標記シンポジウムを下記により開催いたしますので，ふるってご応募下さいますようご案内いたします。

1. 日 時 12 月 21 日 (火)

2. 会 場 農林水産省 農業環境技術研究所講堂

干305 茨城県つくば市観音台 3-1-1 電話 0298-38-8204

(1)常磐線牛久駅下車，農林団地経由筑波大学中央（筑波センター）行きバス，農業環境技術研 究所前下車, 徒歩 5 分, または常磐線荒川沖駅よりタクシー 15 分

(2)東京駅八重洲口より, 筑波山行き高速バス（2 時間に 1 本）で農林団地中央下車, 徒歩 10 分 (3)東京駅八重洲口より，筑波センター行き高速バスで筑波センター下車，タクシー10 分また は牛久駅行きバス, 農業環境技術研究所前下車, 徒歩 5 分

3. 共. 催 地震学会, 土木学会, 日本海洋学会, 日本風工学会, 日本気像学会, 日本建築学会, 日本航空 宇宙学会, 日本農業気象学会 (幹事学会), 日本流体力学会, 日本林学会, 日本地理学会

4. 開催要領 1 講演 15 分程度

前刷り集は作成しません。

5. 申込方法 題目, 講演者氏名 (連名の場合は講演者にO印), 所属学会, 勤務先 (電話, FAX), 100 字 程度の要旨, スライド・OHP の使用別等を記入

6. 申 込 先 $\bar{T} 305$ 茨城県つくば市大わし 1-2 熱帯農業研究センター環境資源利用部 真木太一 （日本農業気象学会「風に関するシンポジウム」係）

電話 0298-38-6355 FAX 0298-38-6316

7. 申込締切9月15日必着

8. 懇 親 会 講演終了後開催の予定

「变動気候下での緑資源と食糧生産に関する国際シンポジウム」(共慛) プロシーディングス購入方法について

本会共催で 1992 年 10 月に開催された「変動気候下での緑資源と食糧生産に関する国際シンポジウム」の プロシーディングスが, 1 冊 4,000 円で販売されております. 興味をお持ちの方は, 下記へお申し込み下さい. 申し込み先 テ305 つくば市観音台 3-1-1 農業環境技術研究所 気象管理科内 国際シンポジウム事務局 電話 0298-38-8204 FAX 0298-38-8199

支払いにはプロシーディングス送付時に同封する郵便振替用紙をご利用下さい，

\section{各種学術賞・研究奖励金候補者の公募について}

\section{第 1 回日産科学賞候補者推薦について}

1. 対 象 自然科学分野（人文・社会科学分野との複合領域を含む）で，下記により学術文化の向上発展に 大きな貢献をした満 50 歳未満（1994 年 3 月末時点）の公的研究機関に所属する研究者. 2 名. a) 学術研究上重要な発見をした，b）新しい研究分野を開拓した者.

2. 賞 記念品ならびに副賞として研究助成金 500 万円

推薦を希望される会員は, 所定の用紙（175 月切手を同封のうえ, 下記へ請求のこと）に必要事項を記入の うえ，8月19日（木）までに常任委員会あてにご提出下さい，常任委員会にて推薦を決定いたします，詳細 は学会事務所までお問い合わせ下さい.

干104 中央区銀座 6-17-2 財団法人 日産科学振興財団研究助成係 電話 03-3543-5597 


\section{第 20 回（平成 5 年度）日産学術研究助成候補推萀について}

日産科学振興財団より「日産学術研究助成」の候補研究推薦依頼がありましたので，お知らせいたします。

1. 分 野 1) 人間と機器とのかかわりに関する研究，2）資源・エネルギーに関する研究，3）自然環境およ び都市環境に関する研究，4）新しい機能材料に関する研究，5）生命現象に関する研究

2 . 助成対象・内容

一般研究 $\mathrm{A}$ : 研究期間が長期にわたる研究, 学際的グループ研究等 (共同研究に限る). 1 件 1,500 万円限度, 採択 10 件程度, 期間 $2 \sim 3$ 年.

一般研究 B : きわめて創造性に富む短期的な研究, 本格的な研究に取り組むための調査・予備研 究 (共同研究に限る). 1 件 300 万円限度, 採択 15 件程度, 期間 1 年.

奨励 研 究: 若手研究者の萌芽的 ·独創的な個人研究. 1 件 200 万円程度, 採択 35 件程度, 期 間 1 年.

3. 選 考 財団の選考委員会において選考のうえ, 理事会で決定.

推薦を希望される会員は, 所定の用紙 (175 円切手を同封のうえ, 下記へ請求のこと) に必要事項を記入の うえ，8月19日（木）までに常任委員会あてにご提出下さい，常任委員会にて推薦を決定いたします．詳細 は学会事務所までお問い合わせ下さい.

干104 中央区銀座 6-17-2 財団法人 日産科学振興財団研究助成係 電話 03-3543-5597

FAX 03-3543-5598 


\section{THE ASSOCIATION OF JAPANESE GEOGRAPHERS 1992 1993}

President......Tsuneyoshi UKITA

Auditors.......Kenryo AsHiKAGA, Yasuhiko YAMADA

Executive Committee.......Kazuo NAKAMURA

Members: Takeei Kolzumi (General Affaires), Eiichi Aoki (Cheif Editor of Series A), Hiroo OHMORI (Treasury), Takasuke SuzUKI (Liaison), Akira TABAYAsHI (Planning), Nobuyuki YoneKuRA (Meeting Affairs), Isao SAITO (Chief Editor of Series B)

Council …...Eiichi AOKI, Nobuyoshi AokI, Kenryo AsHikAgA, Tadashi ARAI, Shoichiro Arizono, Hiroshi IKEdA, Hiroshi IsHiHARA, Katsutaka ITAKurA, Takeo ICHIKAWA, Yasuo Ito, Terumichi Osako, Yoko OTA, Toshiaki OHJI, Hiroo OHMORI, Takashi OGUCHI, Takashi OKuno, Yugo Ono, Isamu KaYAnE, Takeshi Kawamura, Kenji Kitagawa, Akihiro Kinda, Masayoshi Kusaka, Tadanori KuWABARA, Takashi KoAze, Takeei KoIZUmi, Isao SAITo, Yoshiaki SAKAGUCHI, Hiroshi Shitara, Takasuke Suzuki, Hiroki TAK amura, Keiichi Takeuchi, Akira TABAyashi, Toshikazu TAmURA, Takashi Todokoro, Kazuo NA KAmURA, Osamu Nishikawa, Hideki Nozawa, Noboru Hida, Yukio HimiYama, Kazuo FUKAISHI, Yasuo MASAI, Makoto MuraKAmi, Hiroshi MorikAwA, Toshifumi YADA, Yasuhiko YAMADA, Akihisa Yoshikoshi, Masatoshi Yoshino, Akira YOSHIYAMA, Nobuyuki YoNEKURA

\section{公示}

日本地理学会選挙管理委員会

本年度は会長・評議員・会計監査・常任委員長ならびに常任委員の選挙の年となっており, 選挙管理委員会 では 7 月 1 日現在で選挙人名簿の確定作業を行ないます。つきましては, 住所・所属・氏名等に变更のあった 方で，まだ变更手続きを済ませていない方は，6月30日（水）までに会員名簿の訂正カードまたは官製葉書 にてご一報下さい（電話での連絡, 地理学評論第 4 号に緅じ込んである入会申込書を使っての連絡はご遠慮下 さい).

編集専門委員一一青木栄一(委員長) 大崎 晃 岡 秀一 栗原尚子 黒坂裕之 高阪宏行 斉藤享治 竹内淳彦 田瀬則雄 千葉立也 手塚 章 東郷正美 徳永英二 富田和暁 福原正弘 松倉公憲 松村祝男 山下脩二 山村順次 (書記) 細井久恵

本誌の刊行にあたっては文部省科学研究費補助金 (研究成果公開促進費) の援助をうけた.

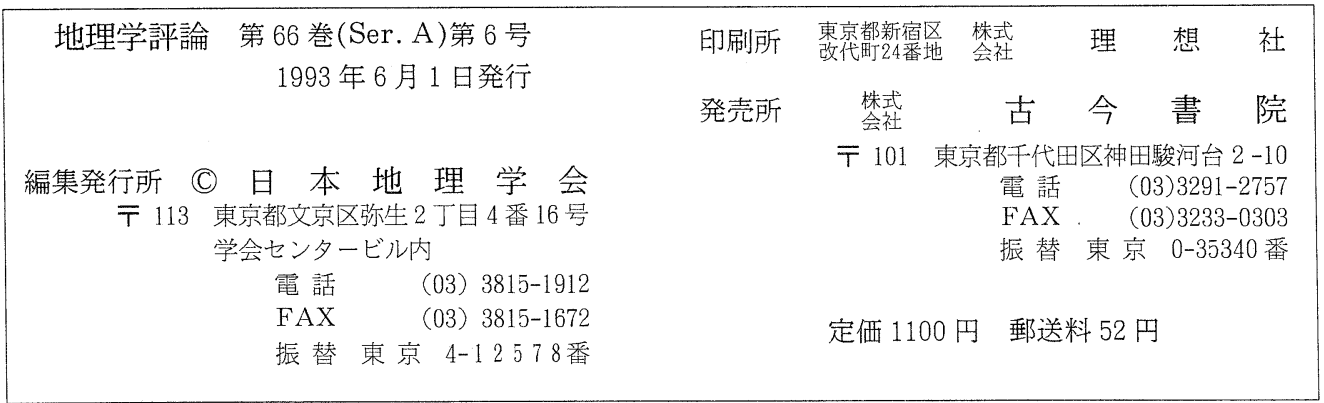

